\title{
Focal Segmental Glomerulosclerosis Secondary to Juxtaglomerular Cell Tumor during Pregnancy: A Case Report
}

\author{
Yasushi Ohashi $^{a} \quad$ Shizuka Kobayashi $^{a} \quad$ Taichi Arai $^{a} \quad$ Tetsuo Nemoto $^{b}$ \\ Chizu Aoki $^{\mathrm{c}}$ Masato Nagata ${ }^{\mathrm{d}}$ Ken Sakai $^{\mathrm{a}}$

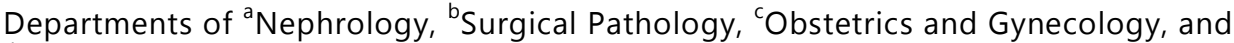 \\ dUrology, School of Medicine, Faculty of Medicine, Toho University, Tokyo, Japan
}

\section{Key Words}

Focal segmental glomerulosclerosis · Hypertension · Pregnancy · Renin secretion

\begin{abstract}
Juxtaglomerular cell tumor is a rare renal neoplasm. Secondary hypertension with juxtaglomerular cell tumor can be seen in females in their 20s and 30s. We present a case of juxtaglomerular cell tumor during pregnancy. A 32-year-old female was hospitalized for refractory hypertension and nephrotic syndrome in the 23rd gestational week. One year before admission, she had been diagnosed with hypertension; plasma renin activity at that time had been $2.3 \mathrm{ng} / \mathrm{ml} / \mathrm{h}$. Her blood pressure was uncontrolled during pregnancy, and proteinuria was detected in the 12th gestational week despite the administration of antihypertensive medications. Laboratory data showed proteinuria, hypokalemia, and hypoalbuminemia. In the 25th gestational week, she underwent surgical termination of the pregnancy because of congestive heart failure and acute renal injury. After the termination of the pregnancy and the delivery of a viable fetus, her hypertension and nephrotic syndrome were found to persist with a high plasma renin activity $(13 \mathrm{ng} / \mathrm{ml} / \mathrm{h})$. Ultrasonography showed a $5.5-\mathrm{cm}$ left renal cystic mass with a partially solid component at the lower renal pole. The left kidney with the renal mass was excised by laparoscopic nephrectomy. Plasma renin activity normalized the next day, with a decrease in blood pressure to $120-130 / 80-90$ $\mathrm{mm} \mathrm{Hg}$; however, proteinuria remained at $\geq 3.5 \mathrm{~g} /$ day. On the basis of histopathological findings, the patient was diagnosed with a juxtaglomerular cell tumor and focal segmental glomerulosclerosis. Juxtaglomerular cell tumor is a rare renin-secreting tumor associated with refractory hypertension in young females and is a possible cause of hypertension during pregnancy.




\section{Introduction}

Juxtaglomerular cell tumor is a rare renal neoplasm. The main clinical manifestation is hypertension with excessive renin secretion $[1,2]$. Most cases of secondary hypertension due to juxtaglomerular cell tumor occur in females in their 20s and 30s [3]. Four cases of juxtaglomerular cell tumor in patients with hypertension detected during pregnancy have been described [4-7]. Of these, 2 cases resulted in miscarriage and fetal death [4, 6]. The other two cases were thought to be associated with juxtaglomerular cell tumor leading to hypertension during pregnancy, which was diagnosed several years after delivery [5, 7]. We present a case of nephrotic syndrome due to hypertension secondary to juxtaglomerular cell tumor during pregnancy.

\section{Case Report}

A 32-year-old female was hospitalized and referred to the Kidney Center for refractory hypertension and nephrotic syndrome in the 23rd gestational week. Initially, superimposed preeclampsia was suspected. She had a 1-year history of essential hypertension before admission, which had been diagnosed as essential hypertension because no endocrinological or urinary sediment abnormalities had been detected at that time; plasma renin activity and serum aldosterone level had been $2.3 \mathrm{ng} / \mathrm{ml} / \mathrm{h}$ (reference range $0.3-5.4 \mathrm{ng} / \mathrm{ml} / \mathrm{h}$ in the standing position) and $170 \mathrm{pg} / \mathrm{ml}$ (reference range $38.9-307 \mathrm{pg} / \mathrm{ml}$ in the standing position), respectively. In the 5th gestational week, her blood pressure had been 170/108 $\mathrm{mm} \mathrm{Hg}$, despite receiving a combination of hydralazine hydrochloride and methyldopa. Proteinuria had been detected in the 12th gestational week. Laboratory data had been significant for proteinuria $(9.8 \mathrm{~g} /$ day), hypokalemia $(2.8 \mathrm{mmol} / \mathrm{l})$, hypoalbuminemia $(1.9$ $\mathrm{g} / \mathrm{dl})$, hypercholesterolemia $(274 \mathrm{mg} / \mathrm{dl})$, and a fractional sodium excretion of $0.1 \%$. Her blood pressure remained uncontrolled after admission despite receiving comprehensive medical therapy. This led to the development of congestive heart failure, with her body weight increasing from 46.5 to $62.8 \mathrm{~kg}$, and acute renal injury, with creatinine levels increasing from 0.51 to $0.99 \mathrm{mg} / \mathrm{dl}$. Eventually, she underwent surgical termination of the pregnancy in the 25th gestational week and delivered a viable fetus weighing $606 \mathrm{~g}$.

After the procedure, the patient's acute renal injury and congestive heart failure improved for a short period following treatment with albumin and furosemide. However, she was still hypertensive with $140-150 / 80-90 \mathrm{~mm} \mathrm{Hg}$, and proteinuria persisted in the nephrotic range. Laboratory data still showed proteinuria ( $3.7 \mathrm{~g} /$ day), hypokalemia (serum potassium $2.8 \mathrm{mmol} / \mathrm{l}$ ), and hypoalbuminemia (serum albumin $2.7 \mathrm{~g} / \mathrm{dl}$ ). The fractional excretions of sodium and urea were 1.3 and 51\%, respectively. Free water clearance and electrolyte-free water clearance were -0.12 and $0.25 \mathrm{ml} / \mathrm{min}$, respectively. The transtubular potassium gradient was 7.9, indicating the presence of aldosteronism. Plasma renin activity was increased (13 ng/ml/h; reference range $0.3-2.9 \mathrm{ng} / \mathrm{ml} / \mathrm{h}$ in the supine position), and the serum aldosterone level was normal $(133 \mathrm{pg} / \mathrm{ml}$; reference range $22.9-159 \mathrm{pg} / \mathrm{ml}$ in the supine position) 20 days after pregnancy termination, prompting a suspicion of the presence of renovascular hypertension. Ultrasonography and magnetic resonance imaging detected a $5.5-\mathrm{cm}$ left renal cystic mass with a partial solid component and early contrast enhancement at the lower renal pole (www.karger.com/doi/10.1159/000362757, online suppl. fig. S1 and S2). A final diagnosis of secondary hypertension due to a renin-secreting tumor (with a plasma renin activity of $7.3 \mathrm{ng} / \mathrm{ml} / \mathrm{h}$, a high serum renin level of $186 \mathrm{pg} / \mathrm{ml}$, and a serum aldosterone level of $456 \mathrm{pg} / \mathrm{ml}$ ) was made 40 days after pregnancy termination, and her 
blood pressure was controlled to 120-130/80-90 mm Hg with nicardipine and methyldopa. 100 days after pregnancy termination, the left kidney with the renal mass was excised by laparoscopic nephrectomy. The plasma renin activity and serum renin level normalized the day after surgery. However, proteinuria remained in the range of 1-2 g/day, although it showed a decreasing trend.

Figure 1 presents the histopathological characteristics of the tumor lesion. The specimen was collected during left radical nephrectomy; the tumor measured $55 \times 45 \times 25 \mathrm{~mm}$ and was poorly circumscribed and unencapsulated. The cut surface was grayish-white to yellowish-white, with necrosis and hemorrhaging in the center. Microscopically, the tumor was composed of round or spindle-shaped cells containing polygonal nuclei with clear or eosinophilic cytoplasm. Mitotic activity and abnormal mitosis were not observed. Immunohistochemical staining for anti-renin antibody (AnaSpec, Inc., Fremont, Calif., USA) showed a punctate positivity in the perinuclear cytoplasm of some tumor cells. The tumor cells stained positive for $\alpha$-smooth muscle actin and negative for cytokeratin (CAM5.2), epithelial membrane antigen, and melanoma-associated antigen (HMB-45). The unaffected renal parenchyma showed segmental glomerulosclerosis in $22 \%$ of the glomeruli (fig. 2), which was observed mainly as segmental areas of sclerosis with capillary collapse on the vascular pole (fig. 3a). Smooth muscle cell proliferation was pronounced in the afferent and efferent arterioles near the vascular pole (fig. 3a, b). However, a segmental area of sclerosis was also observed on the urinary pole (fig. 3c). Moreover, collapses of the glomerular tufts and cell proliferation on Bowman's capsular epithelium were observed (fig. 3d). Thus, the histological findings exhibited mixed morphological variants and could not be categorized as any specific variant by the Columbia classification. Global glomerular sclerosis was observed in 2 of 94 glomeruli. Glomerular hypertrophy and occlusion of capillary lumens by swelling of the endocapillary cells were not observed. Glomerular endotheliosis was also not observed in the electron micrograph. Intimal thickening was observed in the small arteries; however, no onionskin lesions were present.

Written and signed informed consent was obtained from the patient for the publication of this case report with accompanying images.

\section{Discussion}

This is the fifth reported case of juxtaglomerular cell tumor during pregnancy. More importantly, however, this is the first report of the histopathological findings of both juxtaglomerular cell tumor lesion and focal segmental glomerulosclerosis lesion due to hypertension secondary to juxtaglomerular cell tumor during pregnancy.

At least 4 cases of juxtaglomerular cell tumor during pregnancy have been reported [47]. The first case had hypertension and proteinuria in the 16th gestational week and a miscarriage after nephrectomy in the 19th gestational week [4]. In the second case, the patient was diagnosed with hypertension in the 20th gestational week, leading to fetal death in the 28th gestational week [6]. In the other two cases, hypertension was first noted during pregnancy and juxtaglomerular cell tumors were diagnosed several years after delivery, with no information available about the pregnancy [5, 7]. Juxtaglomerular cell tumor is relatively prevalent in females in their 20s and 30s [3]. Therefore, it is likely that pregnancy may occur in the presence of juxtaglomerular cell tumor. In the present case, a reninsecreting tumor was not suspected until after pregnancy termination when the patient's blood pressure remained uncontrolled. She was treated as a case of severe superimposed 
preeclampsia during pregnancy. Moreover, our patient did not undergo renal ultrasonography during pregnancy, leading to a delay in the diagnosis.

The diagnosis was confirmed on the basis of renin positivity in the cytoplasm and perinuclear area and a suppression of renin activity after nephrectomy. The pathobiological aspects of juxtaglomerular cell tumor have been reviewed [8-10]. Renin positivity has been observed in some cases of renal cell cancer and renal oncocytoma [11]. A-smooth muscle actin positivity is a feature consistent with the diagnosis of juxtaglomerular cell tumor, whereas negative immunohistochemical staining for CAM5.2, epithelial membrane antigen, and HMB-45 is consistent with the absence of renal epithelial tumors and an epithelioid angiomyolipoma [8-10].

Superimposed preeclampsia is characterized by an exacerbation of hypertension and proteinuria after the 20th gestational week [12]. Secondary focal segmental glomerulosclerosis, a result of an adaptive response to glomerular hypertrophy and hyperfiltration, can be caused by hypertension [13] as well as severe preeclampsia [14, 15]. However, whether a renin-secreting tumor is associated with focal segmental glomerulosclerosis is unclear. Theoretically, focal segmental glomerulosclerosis can occur due to secondary hypertension caused by a renin-secreting tumor. However, no report has discussed the relationship between these two diseases. In this case, proteinuria occurred in the 12th gestational week and progressed to nephrotic syndrome in the 23rd gestational week, with a diagnosis of focal segmental glomerulosclerosis with smooth muscle cell proliferation in the afferent and efferent arterioles and various morphological variants of focal segmental glomerulosclerosis. Glomerular hypertrophy, extended nephron loss, glomerular endotheliosis, and onionskin lesions in the small arteries were not observed; however, intimal thickening was observed in the arteries. These findings suggest that focal segmental glomerulosclerosis was due to hypertension secondary to juxtaglomerular cell tumor that predated pregnancy and rapidly deteriorated after the breakdown of pregnancy adaptations after the 20th gestational week. Renal adaptations for pregnancy or endotheliosis were not detected. Vasodilatation of the afferent and efferent arterioles was, however, present.

Nishimoto et al. [14] proposed that glomerular hypertrophy is reversible by approximately 40 days after delivery. In this case, histological findings persisted 100 days after pregnancy termination, which could be a reason for no detectable signs of glomerular hyperfiltration. This may suggest that pregnancy termination and the addition of antihypertensive treatment contributed to a reduced glomerular filtration pressure. Therefore, we consider that pregnancy may have only exacerbated secondary focal segmental glomerulosclerosis associated with a renin-secreting tumor that was present before the 20th gestational week. A previous report, which stated that hypertension and proteinuria occurred in the 16th gestational week, supports this suggestion [4]. Moreover, this case does not fulfill the diagnostic criterion of superimposed preeclampsia - in which proteinuria increases after the 20th gestational week - because proteinuria was found to increase before the 20th gestational week, suggesting the presence of an underlying disease other than preeclampsia.

In summary, juxtaglomerular cell tumor is a rare renin-secreting tumor associated with refractory hypertension. Despite its overall rarity, this tumor is relatively prevalent in young females. The possibility of a juxtaglomerular cell tumor should be considered in cases of refractory hypertension during pregnancy, particularly when there is evidence of exacerbated hypertension and proteinuria in the early phase of pregnancy. 


\begin{tabular}{l|l}
\hline \multicolumn{2}{l}{ Case Rep Nephrol Urol 2014;4:88-94 } \\
\hline DOI: 10.1159/000362757 & $\begin{array}{l}\text { ○ 2014 S. Karger AG, Basel } \\
\text { www.karger.com/cru }\end{array}$ \\
\hline
\end{tabular}

Ohashi et al.: Focal Segmental Glomerulosclerosis Secondary to Juxtaglomerular Cell Tumor during Pregnancy: A Case Report

\section{Acknowledgments}

We wish to thank Dr. Yoji Nagashima for the histopathological staining for renin and for providing important inputs about the case.

\section{Conflicts of Interests}

The authors declare no conflicts of interest.

\section{References}

1 More IA, Jackson AM, MacSween RN: Renin-secreting tumor associated with hypertension. Cancer 1974;34:2093-2102.

-2 Conn JW, Cohen EL, Lucas CP, McDonald WJ, Mayor GH, Blough WM Jr, Eveland WC, Bookstein JJ, Lapides J: Primary reninism. Hypertension, hyperreninemia, and secondary aldosteronism due to renin-producing juxtaglomerular cell tumors. Arch Intern Med 1972;130:682-696.

3 Têru B: Juxtaglomerular cell tumor; in Eble JN, Sauter G, Epstein JI, Sesterhenn JA (eds): World Health Organization Classification of Tumours. Pathology and Genetics of Tumours of the Urinary System and Male Genital Organs. Lyon, IARC Press, 2004, pp 72-73.

4 Henderson NL, Mason RC: Juxtaglomerular cell tumor in pregnancy. Obstet Gynecol 2001;98:943-945.

5 Kim HJ, Kim CH, Choi YJ, Ayala AG, Amirikachi M, Ro JY: Juxtaglomerular cell tumor of kidney with CD34 and CD117 immunoreactivity: report of 5 cases. Arch Pathol Lab Med 2006;130:707-711.

-6 Lachvac L, Svajdler M, Valansky L, Nagy V, Benicky M, Frohlichova L, Nyitrayova O: Juxtaglomerular cell tumor, causing fetal demise. Int Urol Nephrol 2011;43:365-370.

-7 Shin YS, Cha JS, Kang MJ, Park JK, Kim HJ, Kim MK: Newly developed hypertension due to juxtaglomerular cell tumor in pregnancy. Clin Nephrol 2012;78:325-327.

-8 Kuroda N, Gotoda H, Ohe C, Mikami S, Inoue K, Nagashima Y, Petersson F, Alvarado-Cabrero I, Pan CC, Hes O, Michal M, Gatalica Z: Review of juxtaglomerular cell tumor with focus on pathobiological aspect. Diagn Pathol 2011;6:80.

-9 Sakata R, Shimoyamada H, Yanagisawa M, Murakami T, Makiyama K, Nakaigawa N, Inayama Y, Ohashi K, Nagashima Y, Yao M, Kubota Y: Nonfunctioning juxtaglomerular cell tumor. Case Rep Pathol 2013;2013:973865.

$>10$ Martin SA, Mynderse LA, Lager DJ, Cheville JC: Juxtaglomerular cell tumor: a clinicopathologic study of four cases and review of the literature. Am J Clin Pathol 2001;116:854-863.

11 Tomita T, Poisner A, Inagami T: Immunohistochemical localization of renin in renal tumors. Am J Pathol $1987 ; 126: 73-80$

$\$ 12$ Report of the National High Blood Pressure Education Program Working Group on High Blood Pressure in Pregnancy. Am J Obstet Gynecol 2000;183:S1-S22.

13 D’Agati VD, Fogo AB, Bruijn JA, Jennette JC: Pathologic classification of focal segmental glomerulosclerosis: a working proposal. Am J Kidney Dis 2004;43:368-382.

14 Nishimoto K, Shiiki H, Nishino T, Kimura T, Sasaki Y, Yamasaki M, Morikawa H, Fujimoto S, Dohi K: Glomerular hypertrophy in preeclamptic patients with focal segmental glomerulosclerosis. A morphometric analysis. Clin Nephrol 1999;51:209-219.

15 Nochy D, Heudes D, Glotz D, Lemoine R, Gentric D, Bruneval P, Bariéty J: Preeclampsia associated focal and segmental glomerulosclerosis and glomerular hypertrophy: a morphometric analysis. Clin Nephrol 1994;42:9-17. 
Ohashi et al.: Focal Segmental Glomerulosclerosis Secondary to Juxtaglomerular Cell Tumor during Pregnancy: A Case Report
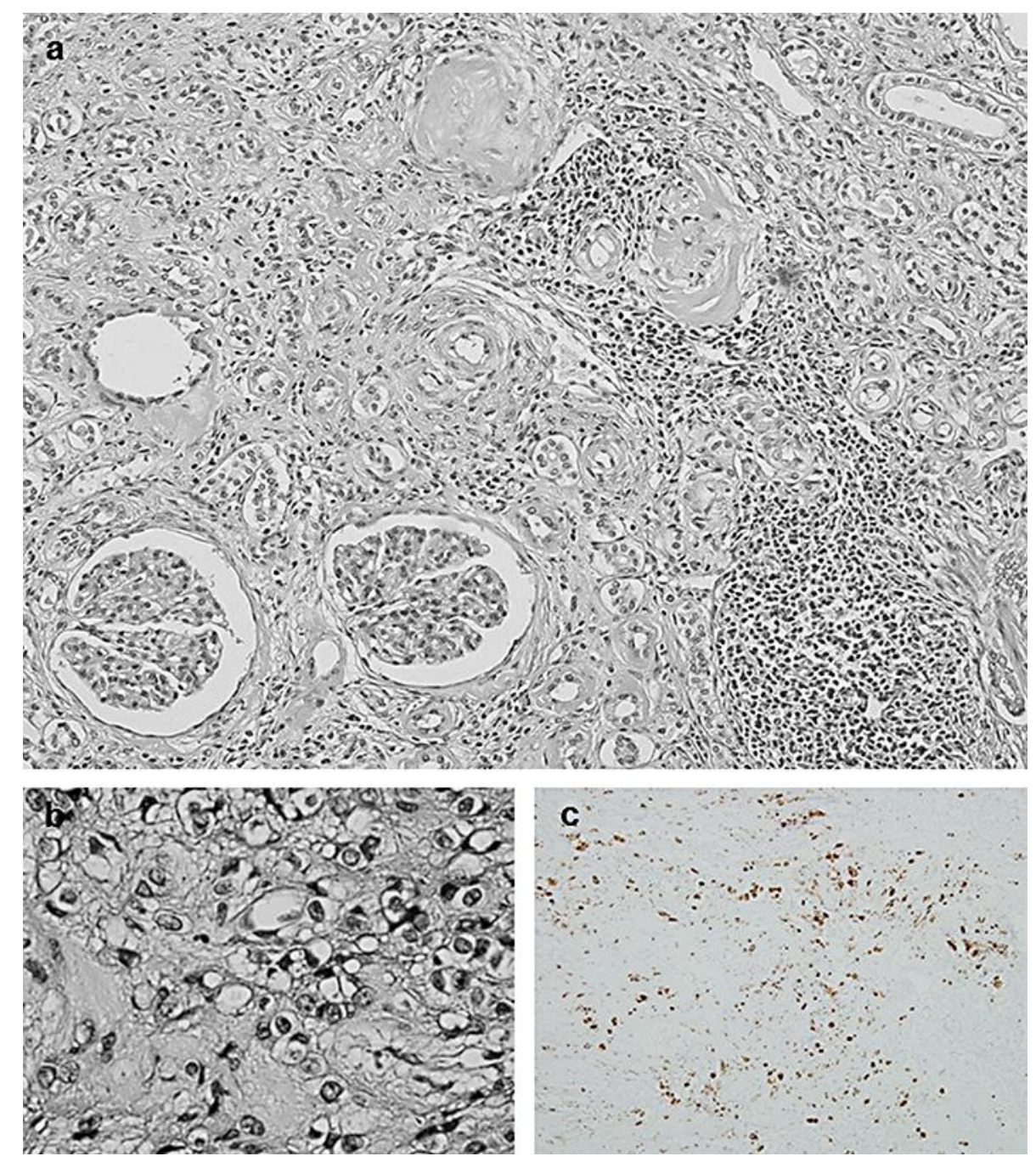

Fig. 1. a Microscopic findings of the tumor lesion (periodic acid-Schiff stain. $\times 200$ ). Light micrograph shows a border configuration of the tumor. Glomeruli are surrounded by the tumor lesion. $\mathbf{b}$ Microscopic findings of the tumor lesion (periodic acid-Schiff stain. $\times 400$ ). The tumor is composed of round or spindleshaped cells containing polygonal nuclei with clear or eosinophilic cytoplasm. Mitotic activity and abnormal mitosis are not observed. c Immunohistochemical staining for renin. Immunohistochemical staining for anti-renin antibody shows a punctate positivity in the cytoplasm and perinuclear area of some tumor cells (immunohistochemistry. $\times 200$ ). 


\section{Case Reports in \\ Nephrology and Urology}

\begin{tabular}{l|l}
\hline Case Rep Nephrol Urol 2014;4:88-94 & \\
\hline DOI: $10.1159 / 000362757$ & $\begin{array}{l}\text { @ 2014 S. Karger AG, Basel } \\
\text { www.karger.com/cru }\end{array}$ \\
\hline
\end{tabular}

Ohashi et al.: Focal Segmental Glomerulosclerosis Secondary to Juxtaglomerular Cell Tumor during Pregnancy: A Case Report

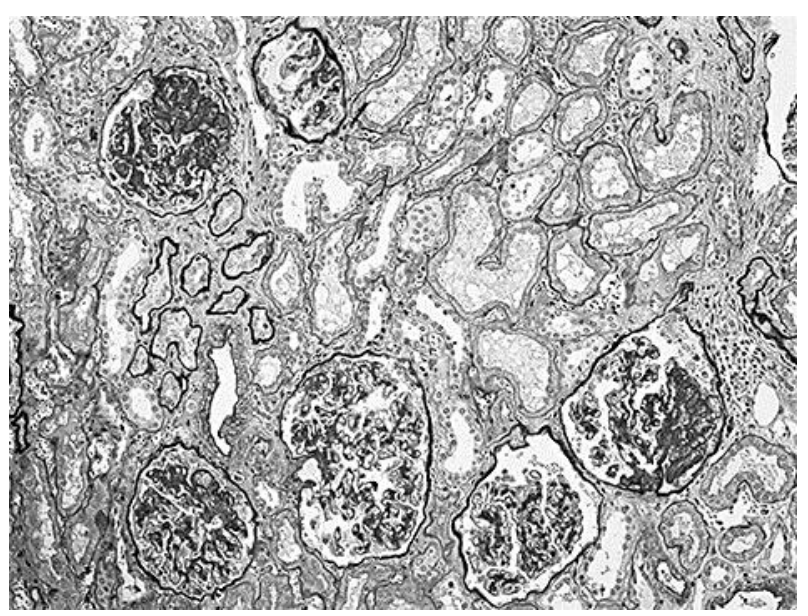

Fig. 2. Microscopic findings of normal kidney tissue (periodic acid-Schiff stain. $\times 200$ ). Light micrograph shows the presence of focal segmental glomerulosclerosis.

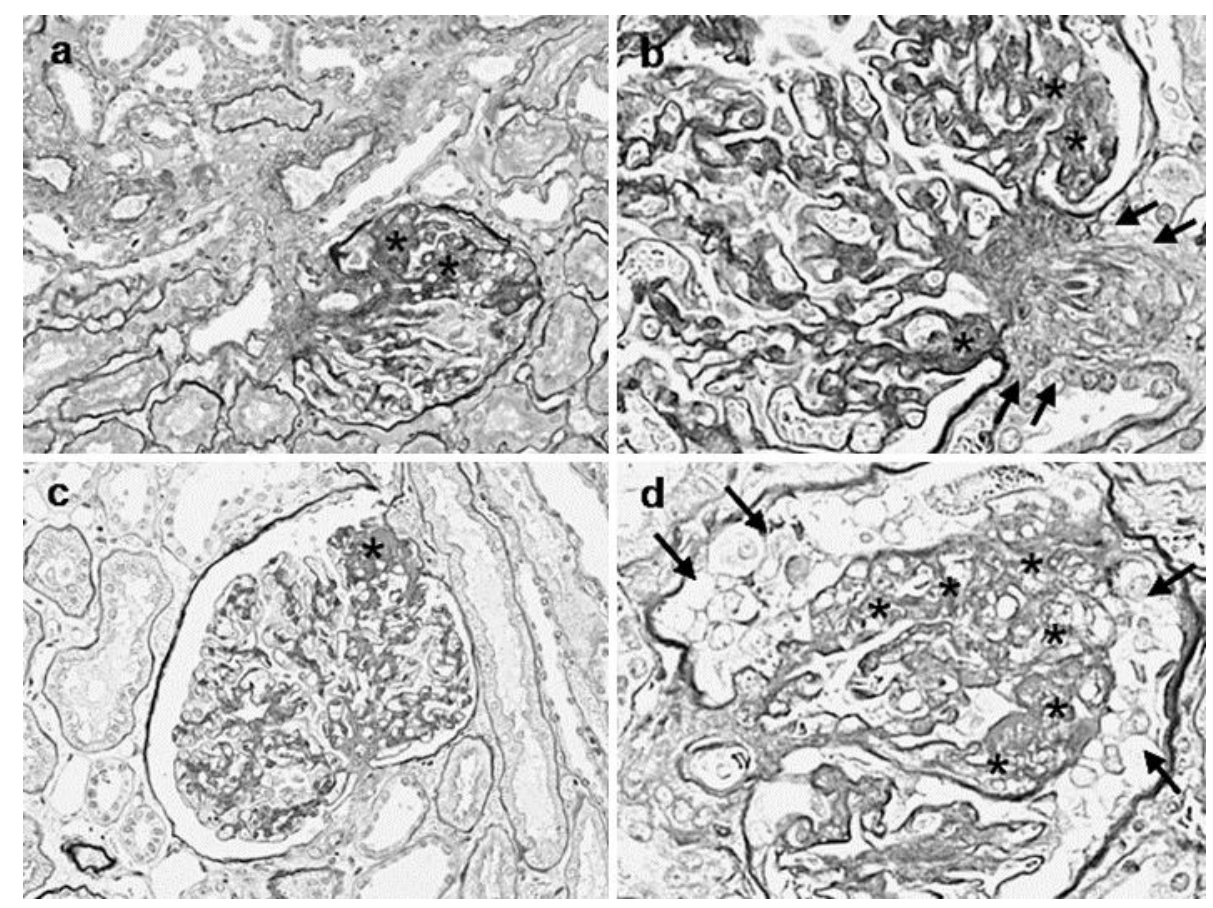

Fig. 3. Histological characteristics of focal segmental glomerulosclerosis. a Light micrograph shows a segmental area of sclerosis with capillary collapse on the vascular pole (asterisks). b Light micrograph shows a segmental area of sclerosis with capillary collapse on the vascular pole (asterisks) and smooth muscle cell proliferation on the vascular pole (arrows). c Light micrograph shows a segmental area of sclerosis on the urinary pole (asterisk). d Light micrograph shows the collapses of glomerular tufts (asterisks) and cell proliferation on Bowman's capsular epithelium (arrows). 